\title{
E D) Counting the Dead in a Decade of Conflict and Controversy
}

\author{
Edward J. Mills, MSc, PhD, LLM, and Frederick M. Burkle Jr, MD, MPH, DTM
}

I $\mathrm{n}$ this issue of Disaster Medicine and Public Health Preparedness, Coghlan et al from the International Rescue Committee (IRC) report on their latest health and mortality outcomes assessment from the Democratic Republic of Congo (DRC), the fifth national assessment by the IRC. ${ }^{1}$ This nationwide report is important for a number of reasons, chief among them the profiling of loss of life among this neglected population. It also raises important considerations for the conduct of health and mortality surveys in any unstable setting, given that it addresses the need for goodquality evidence to inform political decision making rather than allowing political decision making to inform or dictate evidence.

\section{INDIRECT DEATHS}

In the time period that IRC conducted this study, January 2006 to April 2007, DRC was comparatively peaceful, without an active conflict. Despite the absence of conflict, IRC demonstrated that mortality rates were well above the expected mortality rates for DRC before its major conflicts, as estimated by the United Nations Children's Fund in 1998 (crude mortality rate [CMR] of $1.3 / 1000 /$ month). In fact, only $0.4 \%$ of all reported deaths were attributed to violence ( $0.6 \%$ in the recently violent eastern region). They report that, compared with their 2004 assessment's findings, violent deaths now appear to be isolated events and not indicative of health conditions. If violent deaths are the prime concern among decision makers, as some have asserted, ${ }^{2,3}$ then one would expect to see a profound decrease in mortality with the absence of violence. This has not been the case according to the IRC assessment.

The majority of deaths in any conflict is indirect deaths, secondary to the violence, related to the breakdown in public health infrastructure, social services, and access to trained health personnel. ${ }^{4,5}$ In settings such as DRC, this is exacerbated by large population movements and displacements, and the inability of the government to rebuild infrastructure during times of peace because of a weakened economy and failed overseas development support. ${ }^{6}$ Although DRC was largely peaceful during the time of the IRC assessment, local concerns over violence from groups such as the Mai Mai and subsequent fighting between DRC troops and National Congress for the Defence of the People, among others, prevent populations from returning to their villages and investing in infrastructure.

Children's health in these settings can be a strong surrogate marker of the strength of health infrastructure. ${ }^{7}$ In this study, $47.2 \%$ of all deaths were in children younger than 5 years, although they were only $19.4 \%$ of the sample population. Preventable deaths such as diarrhea, malaria/fevers, and measles may be indicative of public health infrastructure given that investments in preventive strategies such as bed nets, vaccinations, clean water, and sanitation have large benefits with low cost, but require manpower to request and distribute the services.

\section{THE POLITICAL SPECTRUM OF STUDYING MORTALITY}

Now that there is a well-conducted study demonstrating inflated rates of death in the DRC, it is hoped that international efforts will focus on improving health infrastructure and prolonging peace. It is naive, however, to think that simply publishing a study will attract the attention of international decision makers or convince them to bring about efforts to reduce deaths. Highly influential medical and public health journals are replete with field research accounts that, once published, languish unnoticed without the opportunity to sway or guide policy or politics. Admittedly, other powerful variables are at play in the international security and health arena. Occasionally an opportunity presents itself, however, and arguably the previous surveys by IRC were indeed partially responsible for attracting the attention of the United Nations Security Council and implementing Mission de l'Organisation des Nations Unies (MONUC) peace forces in the region, in 2000.7 Despite controversy, mortality studies that have brought both media scrutiny and political angst force the hand of open debate and dialog.

The Security Council is believed to be the international body charged with the task of restoring and maintaining international peace and security. It is, however, a political body. At this same time, the DRC's elected government was also submitting requests for Security Council action on their state hostilities. This was initially met with "statements of concern" and resolutions issued to foreign states with forces inside DRC, with no enforcement for nonadherence. ${ }^{8}$ Despite overwhelming evidence of mass death in the country, MONUC would take at least another year before deploy- 
ment. At the beginning of 2004 , with 10,800 peacekeepers and after 5.5 years of conflict, the death toll stood at more than 3.9 million people. ${ }^{9}$ Despite active intervention and even Security Council "peace enforcement" military support, this has not resulted in improved health outcomes for the population of DRC. So, given the political nature of international decision making, what role should epidemiological studies play in preventing death?

\section{THE CONTROVERSY OF COUNTING}

To further complicate the role of epidemiology in complex emergencies and unstable settings, there is emerging dissonance among the health community on how to measure mortality. ${ }^{10}$ The recent Iraq war mortality estimates ${ }^{11}$ controversy demonstrated that many academics, epidemiologists, and nonepidemiologists believed that they had a contribution to make to the debate on mortality, regardless of whether they had conducted studies previously or even visited Iraq. ${ }^{10,12}$ Disagreements about the magnitude of civilian deaths in Iraq permitted military forces involved with the war to dismiss the mortality estimates and choose lower estimates of absolute death that were supported by poorly designed studies. ${ }^{10}$ The same controversy is now emerging on DRC. ${ }^{13}$

There is an obvious need for epidemiologists to agree upon methods that are applicable in this field of study and train individuals to improve and refine the methods. Although estimates from well-conducted studies may appear unambiguous to an epidemiologist, critics may exploit the public's unfamiliarity with epidemiological principles such as sampling frames, sample size, and precision (confidence intervals). ${ }^{14}$ Infighting within the field of mortality measurement risks this field being dismissed as noncredible and allows others that prefer strategies of counting mortality only attributable to violence or estimating mortality through mathematical modeling to receive the same, or more, levels of credibility for their estimates, even though mortality can be measured through more rigorous methods, such as surveillance and population-based surveys. ${ }^{10} \mathrm{We}$ are not suggesting that population-based surveys provide perfect estimates of mortality, rather that they are a minimum threshold of quality for assessing mortality in difficult settings. There are emerging resources for investigators learning to design population-based studies. ${ }^{15,16}$

\section{SO WHY COUNT THE DEAD?}

This leaves us with the uncomfortable question of why do we do studies assessing mortality in difficult settings? If they do not translate to obvious benefits for the population or they risk being dismissed over differing ideologies, do we continue to conduct these studies simply for the historical record or our own personal benefit? We may be blindly optimistic, but we recognize that each death is a travesty to the individual and their family and that, at the very least, they deserve to be counted. ${ }^{17}$ As this issue's IRC study demonstrates, now that the fighting is diminishing in DRC, health needs remain.
Unfortunately, indirect death may continue to smolder and rise as long the protective public health infrastructure and systems to deliver these essentials remain elusive.4,18 $\mathrm{Al}$ though military support may have been inadequate to prevent death, we have clear evidence of what works in preventing major public health catastrophes through mass vaccination, bed nets, nutrition, water, and sanitation. ${ }^{19} \mathrm{In}$ vestment in evidence-driven health interventions can rapidly reduce disease-attributable mortality in this setting. ${ }^{20}$ It is now a question of whether health professionals and funding agencies will step up to the challenge that military organizations have not embraced.

\section{About the Authors}

Dr Mills is a senior scientist at the British Columbia Centre for Excellence in HIV/AIDS and a Canada Research Chair in Global Health at University of Ottawa; Dr Burkle, a Woodrow Wilson International Scholar, is Senior Fellow, Harvard Humanitarian Initiative, Harvard University.

Address correspondence and reprint requests to Dr Frederick M. Burkle Jr, 14 Story St, 2nd Floor, Cambridge, MA 02138 (e-mail:fburkle@hsph.harvard.edu).

Received for publication February 23, 2009; accepted March 10, 2009.

\section{Authors' Disclosures}

The authors report no conflicts of interest.

ISSN: 1935-7893 (C) 2009 by the American Medical Association and Lippincott Williams \& Wilkins.

\section{DOI: $10.1097 /$ DMP.0b013e3181a4cb86}

\section{REFERENCES}

1. Coghlan B, Ngoy P, Mulumba F, et al. Update on mortality in the Democratic Republic of Congo: results from a third nationwide survey. Disaster Med Public Health Preparedness. 2009;3:88-96.

2. Alkhuzai AH, Ahmad IJ, Hweel MJ, et al. Violence-related mortality in Iraq from 2002 to 2006. N Engl J Med. 2008;358:484-493.

3. Mills EJ, Burkle FM. Violence-related mortality in Iraq, 2002-2006. N Engl J Med. 2008;359:432.

4. Ghobarah H, Huth P, Russett B. Civil wars kill and maim people-long after the shooting stops. Am Polit Sci Rev. 2003;97:189-202.

5. Human Security Center . Part IV: counting the indirect costs of war. In: Human Security Report 2005: War and Peace in the 21st Century. New York: Oxford University Press; 2005: 127-134.

6. OCHA: Consolidated Appeal: Democratic Republic of Congo Humanitarian Action Plan 2007 Table C: Requirements, Commitments/Contributions, and Pledges per Appealing Organization Report as of 26March-2007. http://ochaonline.un.org/cap2005/webpage.asp?Page $=1504$. Accessed February 14, 2009.

7. Burkle FM, Greenough PG. Impact of public health emergencies on modern disaster taxonomy, planning, and response. Disaster Med Public Health Preparedness. 2008;2:192-199.

8. Hawkins V. History repeating itself. The DRC and the UN Security Council. Afric Secur Rev. 2004;12:47-55.

9. Coghlan B, Brennan RJ, Ngoy P, et al. Mortality in the Democratic Republic of Congo: a nationwide survey. Lancet. 2006;367:44-51.

10. Tapp C, Burkle FM Jr, Wilson K, et al. Iraq War mortality estimates: a systematic review. Confl Health. 2008;2:1.

11. Burnham G, Lafta R, Doocy S, et al. Mortality after the 2003 invasion of Iraq: a cross-sectional cluster sample survey. Lancet. 2006;368:14211428.

12. Burnham G, Roberts L. A debate over Iraqi death estimates. Science. 2006;314:1241.

13. Désaccord sur la mortalité de guerre. La guerre 1998-2004 a-t-elle fait 200 


\section{Editorial}

000 ou 4 millions de morts? Polémique entre démographes et épidémiologistes. http://www.laconscience.com/article.php?id_article $=8138$. Accessed April 9, 2009.

14. Sondorp E. A new tool for measuring the brutality of war. PLoS Med. 2008;5:e249.

15. Checchi F, Roberts L. HPN Network Paper 52: Interpreting and using mortality data in humanitarian emergencies: a primer for non-epidemiologists. Humanitarian Practice Network Web site. 2005. http://www. odihpn.org/report.asp?ID=2749. Accessed April 9, 2009.

16. The Use of Epidemiological Tools in Conflict-affected Populations: Open-access Educational Resources for Policy-makers. London School of Hygiene \& Tropical Medicine Web site. http://www.lshtm.ac.uk/hpu/ conflict/epidemiology. Accessed February 14, 2008.

17. Setel PW, Macfarlane SB, Szreter S, et al. A scandal of invisibility: making everyone count by counting everyone. Lancet. 2007;370:1569_ 1577.

18. Ghobarah HA, Huth P, Russett B. The post-war public health effects of civil conflict. Soc Sci Med. 1996;42:1095-1108.

19. Bryce J, el Arifeen S, Pariyo G, et al. Reducing child mortality: can public health deliver? Lancet. 2003;362:159-164.

20. Jones G, Steketee RW, Black RE, et al. How many child deaths can we prevent this year? Lancet. 2003;362:65-71. 